\title{
The perspective of constructing and organising crime in Europe: an introduction
}

\author{
Petrus C. van Duyne ${ }^{1}$
}

\section{Introduction}

Should the following scenario be considered imaginary? In 2040, the international agreed target of maximum $2^{0} \mathrm{C}$ climate warming-up was exceeded with one degree. A repeated severe drought made the rivers in Europe unnavigable, causing shortages of raw material supplies. This was followed by severe autumn storms and flooding along the shores of the North Sea causing many casualties and damage to civilians and industry. The public indignation was pronounced: "Why have the authorities done nothing?" Though the causal relation between natural disasters and $\mathrm{CO}^{2}$ was still not rock-solid proven, this chain of events and public fear of more catastrophes resulted in climate scepticism being met with open hostility. Consequently European policy makers were driven to radical action. $\mathrm{CO}^{2}$ emission licences were reduced to a minimum and violations brought under a severe a criminal law regime. Unlicensed emitting hot house gases was to be penalised as 'causing severe physical harm', at the same punishment level as qualified assault. That is not all: once this penal clause was accepted, addition criminal legal constructions were applied, such as conspiracy or participation in a criminal organisation, if more than three managers were involved. As the forbidden emission is assumed to make illegal gains which have to be disguised in the books, the offence of money laundering was added to the criminal emission construction. As is normal in legislation, once a new construction is put into the legal system, it soon intertwines with many existing ones, creating a new constructed reality.

1 Visiting Professor at Willem Pompe Institute, Utrecht University, The Netherlands. 
This can also be considered as a warning: be cautious with fears. Still, such a fear-response criminal law scenario is quite common (Van Duyne, 2004). In fact, it is a cast-iron formula in criminal policy making and law enforcement. Fear implies the perception of a threat that has to be fended off and in our ordered society, governed by the rule of law, a common reaction is to resort to criminal law constructions. Threat, risk, fear, or belief in the 'Terrible Snowman', they can all be driving forces for legislation, apart from material and political interests of the law makers. If a substantial part of the population believes in the threat of the 'Terrible Snowman', it is real enough to feed law making. Naturally, the 'Terrible Snowman' fear is a bizarre rhetoric, but is that more bizarre than the criminalisation of homosexuality or blasphemy? Not long ago in the late 1960s that feeling of fear for homosexuality faded (but never fully) making the relevant criminal law constructions obsolete or empty. ${ }^{2}$ Decriminalisation of homosexuality followed in most of the industrialised world - to the joy of the LGBTQ+ communities. But do not dare to be blasphemous and gay (or both) in most of the Muslim countries: that is tempting fate.

Given this importance of emotions in criminal law matters, we can speak of fear management: capturing and maintaining fear, which must be cast in a rational way into a legal mould: legislation and/or budget. Interestingly, once fear is recognised (or fanned) politically, it is unlikely that it will be refuted when no real threat manifests itself. Galeotti (2018) summed up a number of Russian organised crime (OC) threats to the 'West'. But he had to admit that the Russians did not come in the sensational OC outfit or made strategic alliances with the mafias (Rawlinson, 1998). Instead, they came as (criminal) traders which does not stir such high fears. So the fear of "crime from the East" as law enforcement priority, for which in the Netherlands even established a special team (Noord en Oost Nederland), sank into oblivion but the constructions around it lingered on for a while. ${ }^{3}$

2 In Europe decriminalisation of homosexuality started in 1791, in France and Andorra. In England and Wales it was decriminalised in 1967, Scotland 1981 and Northern Ireland 1982.

https://en.wikipedia.org/wiki/Sexual_Offences_Act_1967

3 Kernteam Noord en Oost Nederland, Algemene Criminaliteitsbeeldanalyse Oost Europa, 2000-2001. 
In the 'fear-of' a specific crime there can also be much ambiguity, which may be reflected in the law enforcement response. For example, the governments and employers in many EU industrial sectors realise that the steady retirement of the older workers must be replaced by migrants to keep production and the economy going. At the same time there is a fear of irregular migration. So, a smart law maker must respond to that dual challenge by moderate law enforcement ("doing something") but not so much that the strawberries remain unharvested or the housing construction is delayed. Threat images may also be exploited to arouse resentments and then display the expected law enforcement firmness: "action is taken". Even if refugees are successfully kept out of countries, such as in Poland and Hungary, the constructions to fend off the threat remain literally in the field.

With so many tasks to stem the tide of a multitude of threats and reduce fears, it is not surprising if governments also drop stitches or show ambiguity or (worse), duplicity, in law enforcement. For example, clamping down on corruption, illegal migration and labour exploitation are emotive election themes (feel good), but a strict policy may affect many vested interests in countries with a tradition of mal-governance or in times of labour shortage. This stapling of legal constructions and ambiguous enforcement leads to legal uncertainty, particularly concerning aliens (Herkes, 2018).

\section{Aliens: problematised, criminalised and exploited}

The continuous movement of people is an historic given, whether as homo sapiens 'out of Africa' or as Goths during the Germanic migration (Heather, 2009). One tribe landed as Longobards in North Italy, and shaped the region by threatening the Pope Stefanus who in 754 had to call in the Frankish king Pepin the Short to protect him (Norwich, 2013), with fateful, long lasting consequences. Migrating people have rarely been welcomed, unless explicitly invited as 'guest workers'. In that capacity they are not criminal. But nevertheless, "they steal our jobs". Even if they do not steal or are otherwise not more criminal than the rest of the population, they are put into a criminal 'frame', in particular when their numbers are perceived as overwhelming. Then feelings of unsafety start to spread among the people putting the (local) administration under pressure "to do something". Usually this entails tough 'crimmigration' measures to assuage the people. 
As Anna di Ronco and Anita Lavorgna set out in their chapter, such criminal framing is media supported and rather 'politically neutral' in the sense that political left or right do not differ much in their attitude. The authors analysed the media in two North Italian cities, and did not find much differences in the measures passed by both centre-right and centre-left coalitions. While the tune of the authorities' rhetoric differs somewhat (more sensationalist on the side the Lega), they did not differ much in the application of municipalities' criminal and administrative tools. These are intended to sanction an individual's behaviour when it is deemed to affect the quality of life in the city centres. Protection against perceived criminal harm has turned into reducing 'existential uneasiness' caused by aliens 'littering the public space' and affecting the 'decorum'. Was this criminal approach necessary? Instead of constructing this 'decorum loss' in a criminal frame, the authorities could also consider a non-criminal approach: handing out jackets, ties and other 'decorum enhancing' items to the migrants such that they would not be considered as unsightly and 'littering'.

Of course, 'littering the streets' is not a real migrant's choice. In principle they want to make a living. In the end, if not repatriated, most do so legally. Not all irregular migrants succeed in achieving this desired outcome. Trang Nguyen describes in her chapter the diversity in vicissitudes of Vietnam migrants arriving in Europe. That occurred in three waves and in which the Vietnamese migrants faced various employment 'choices', though as a rule there was not much to choose. Naturally this depends on the (underground) economic opportunities. In the UK many Vietnamese entered the home-grown cannabis industry ('gardener teams') and in Germany they found an income in the Berlin illegal cigarette market (Nguyen and von Lampe, 2018). Often the previous wave of Vietnamese was already moving towards legal employment and leaving their market place to the newcomers. It testifies to the resilience and dynamism of the Vietnamese enterprising spirit in the underground market. But this is not without hardship and many shattered hopes of earning enough to pay off the smuggling debt and send money home. This financial flow back to Vietnam is also advantageous the Vietnamese government, who willingly and knowingly furthers this migration, particularly from impoverished rural regions. Corruption and deceit are common in this migration business, which blurs the dividing line between state organised migration, and irregular migration with the accompanying smuggling and trafficking. 
This ambiguous situation is not unique. In a provocative chapter on transnational crime of Chinese origin in the EU Jurij Novak sheds light on the criminal landscape, in which migrants move to and fro, some smuggled, others trafficked, and some migrants operating as seemingly legal entrepreneurs, but fraudulently cutting edges to remain competitive with their local semi-legal branch. His chapter describes the highly confusing situation of the Chinese migrant workers in the Chinese garment industry in the city of Prato, Italy. First, the author does away with a lot of myths around Chinese Triads and Chinese migration of whatever modality. After tidying up these fanciful constructions, the author elaborates the organisation of crime in the textile and garment industry in Prato. Amidst a large Chinese minority of 30.000 to $40.000^{4}$, of which a substantial part remains illegal in the country, Chinese entrepreneurs have established a partly underground garment industry. With an annual estimated profit of 2 billion Euros they serve any chic Italian brand (or forge them). To keep the production costs low and the products competitive, all kinds of law breaking have been observed. By any legal qualification the labourers can be considered as exploited or in a state of modern slavery. Despite that, they have little victimisation awareness, industriously working in long shifts after which they return to their damp and crowded dormitories. Their main concern is to transmit their savings home. Those who pull the strings lead complex production organisations as 'bourgeois' crime entrepreneurs, dwarfing old fashioned organised criminals. For the author these findings lead to the question: shouldn't we investigate the more serious economic forms of organising crime? That is, not focus on the Chinese human smugglers, but on the wealthy underground entrepreneurs, with a respectful face but meanwhile exploiting his fellow countrymen. A rhetoric question.

State supported or enabled human smuggling of Vietnamese, the legal and illegal working relationships in the Prato Chinese textile industry, these findings provide strong indicators to look at migration and the related 'travel service' from another, more anthropological angle as is done by Dina Siegel (2010) in her previous work as well as in her chapter devoted the refugee crises on the island of Lesbos, Greece. She juxtaposes the crude

\footnotetext{
4 All numbers in this volume will be in normal European notation: a comma for the decimals and a full stop for the thousands.
} 
rhetoric of policy makers and policy documents to the findings of researchers doing field research at site. At the policy makers' side we find the predictable construction of 'ruthless' networks exploiting the vulnerable position of defenceless refugees. If this rhetoric fails to impress it is reinforced by adding that the smuggling is the work of 'organised crime', always a good adjective to enhance the perception of threat. And indeed, there were organised crime groups operating and there are examples of reckless 'services': unseaworthy ships and unsafe life vests given to refugees on overcrowded boats causing numerous casualties. On the other hand, providing 'cross-border travel services' is a purely consensual business interaction in which the service provider rather heeds the principle: "Don't drown your customers". Obviously, doing so or being 'cruel and rapacious' will not further business. In contrast, the author's fieldwork on Lesbos demonstrated that there were many decent 'travel service providers', though not necessarily good Samaritans: they have a business to run. There is also more surrounding business than the core business of illegal transportation. In fact, many inhabitants profited from the parallel economic opportunities. For example, local transport and catering on the island Lesbos which led to substantial price rises for the arriving migrants. This nuanced, ethnographically supported picture underlines the conclusion of the author that clamping down on smugglers does not solve the problem of the flow of migrants: it is ritual dancing far removed from the daily struggle of people who want to leave harmful misery behind.

\section{Recognising and fending off harm and other mischief}

Fleeing misery at home is no guarantee against the fate of landing in other harmful situations in the targeted affluent economies where state and business may enable other forms of exploitation. In cases in which this is unethical there is no crime and one may argue that this goes beyond the narrow borders of criminology. But why? There is no reason to heed these criminal law limitations, according to Jonathan Davies, who looks through the 'lens of harm' beyond these narrow borders, namely at what happens on the workplace and in supply chain contexts in terms of harm. This is a valuable extension to a crime-restricted criminology. Indeed, many harmful conditions on the work floor were legal for decades until they were 
recognised as immoral and, after moral awareness raising actions, considered exploitative and harmful to physical and mental health. In the last resort causing or maintaining such working conditions was criminalised. Nowadays such conditions are approached from the perspective of 'modern slavery'. Developments in labour relationships and working condition should therefore be critically followed also by criminologists: there is an inherent tension between 'sound', meaning cost effective, working processes, and costs saving negligence that may inflict harm to the workers' health and rights. For example, making the corporation leaner and more flexible by dismissing personnel and hiring them back as self-employed enterprises under disadvantageous or harmful conditions: lower pay and no health or labour rights protection. In this way a new proletariat may emerge: 'independent but exploited'. Nevertheless, at the moment not yet categorised as exploitation under a criminal law construction.

Recognising that harm may be inflicted remains inconsequential if not followed by securitisation: the cocktail of laws, local administrative and institutional measures to prevent harm and crime. Such a security or crime prevention cocktail tends to expand to all sides as is set out in the chapter by Anna Di Ronco and Anna Sergi and illustrated with the stiff safety regimes in Italy and the UK. They point at how safety and crime prevention becomes dominant rather through a chain of associations, than through a chain of reasoned arguments. This may work as follows. First, there is nuisance, which is next associated with small crime, which is then connected to serious crime and that again to organised crime, eventually to its 'transnational' manifestation. In fact, 'safety thinking' is shaping a safety construction that knows no boundaries. And what about the principles of proportionality and subsidiarity? These words are repeated at all EU levels time and again, but then become subordinated to safety thinking in which these rational principles hardly play a role. The authors present Italy as a good example where getting a safe and 'clean' public space is a prime priority. Indeed, incivilities, hanging around on squares, making noise or making jibes at passers-by make people feel uncomfortable and unsafe in the public space. Correctly or not, a subsequent associative bridge to crime and irregular migrants is easily made. Basically people with a different appearance are considered 'unwanted' and subjected to administrative punitive measures and bans to make the white middle class feel more comfortable. This security extension is not only an Italian xenophobia driven legal 
construction. In the UK, by a court order one can be severely restricted in one's freedom of movement or coming together in the public space if one is associated with a 'gang', a vaguely defined criminal law concept that leaves the police with a lot of latitude. In the case of drug involvement one is upgraded to 'organised crime'. From the rule of law and the freedom of movement perspective, the EU should scrutinise these limiting legal constructions. However, that would be at odds with its own created European Crime Prevention Network (EUCPN). Will that institution disseminate best practices and at ther same time point at the mitigating requirement of proportionality? The authors express their doubt: in the politicised simplified construction of prevention and fear of crime there little room for this extra dimension. After all, one does not win elections by invoking proportionality when taking advantage of voters' fears is the winning card.

\section{More than mischief: organised crime and business goes on}

What about fear of organised crime? Would that not be an ultimate 'winning card' in elections? Here we have a paradox: indeed, organised crime has for a long time figured on the top of the political priority pyramid (Lampe, 2016). From the late 1980s till the present, the threat image of OC functioned as an associative 'crowbar' argumentation as we saw in the previous chapter: in Italy as well as in the UK 'organised crime' was used to lend the proposed policies more weight: who can oppose a freedom restricting crime prevention policy when the source of harm is allegedly 'organised crime' related. This implies that 'organised crime' remains in the general consciousness as a kind of keynote with a variable volume depending on the 'tune' of other political opportunities. Being a constant tune it is present for adding weight to a theme by adding the bridge-concept 'nexus'. For example the "nexus of . . organised crime". Success guaranteed. Therefore, the way OC is constructed still deserves our critical attention (von Lampe, 2016).

With such multiple use one expects a lot of research activity and an accompanying availability of research funds. Is that the case? In their chapter on research on organised crime in Germany Klaus von Lampe and Susanne Knickmeier refute this expectation: compared to the political interest there is generally a shortage of basic empirical research, with the exception 
of the Netherlands. The authors made a meticulous stock taking and analysis of the OC research landscape in Germany over a period of 2008-2017 for which they collected research projects, dissertation projects and academic publications of German-based researchers on OC issues. This must be seen against the backdrop of the OC situation as presented in numerous police reports and media publications. Contrary to expectation, the type and subjects of research projects did not reflect the public OC image and concerns. In fact, measured by output the picture is fragmented. In general, there is a scarcity of empirical research compared to the large numbers of publicised studies, though in the beginning, around 1990, Germany had taken the lead in Europe. But after 2000, it seems to have lagged behind as is illustrated by the low output from 2008-2014, after which it started to catch up. Nevertheless, there remains a gap between the subjects of public attention in Germany and research interest. For example, the so-called Arabic Clans, outlaw biker groups, and phenomena such as organised residential burglary. It remains to be seen whether recently launched studies into these thematic areas will lead to more than just sporadic research output. One may wonder whether this lack of coherence is due to lack of a proper construction of the OC concept. And if such a construction cannot be drawn up, under the principle of scientific parsimony it should be discarded. That is not done either: the OC flag remains on top, while the underlying reality changes, as the next chapters on Scotland and the Czech Republic demonstrate.

Regarding the construction of OC in Scotland, Kenneth Murray raises the question concerning the working in network relations or in a hierarchy. Though in the criminological literature there is a tendency to interpret OC from the perspective of networks, for the Scottish organised crime landscape the author takes a middle position. Taking the wholesale cocaine traffic as the field of description, he constructs a hierarchic and a network interaction for the handling of the contraband. Unsurprisingly, the wholesale importation of contraband requires hierarchy: access abroad, oversight and scrutiny for the handling along the intermediate transport steps. These are distinctive capabilities that are inherent to a hierarchic organisation. Once the commodities have landed at retail distribution level, there is more need of flexible handling of the goods within network relations. However, for the reverse flow, the financial handling of the revenues, the criminal money management, higher expertise and oversight are required as special 
operational abilities. For this task a hierarchically enforced financial discipline is an essential asset also if financial tasks are out-coursed. Naturally, there may be network relationships between hierarchic organisations. At the end of the chapter we get a warning that the validity of the OC construction may have only a geographic validity: it may mainly apply to the mid-Scotland central belt between Glasgow and Edinburgh. Up north the illicit market landscape appears to be more open. It is a warning to address the validity question seriously: what seems to be a valid construction can evaporate across territories and times. "Panta rhei", all is changing, as Heracleitos would say.

This is almost literally the title of the chapter by Miroslav Scheinost: the changing face of organised crime, as it appears in his description of the past decades in the Czech Republic. The author leads us through the changing landscape of organised crime: from the 'virgin' years of the socialist society, where organised crime was not even thought of, to 'socialist organised crime', to the post-socialist transition epoch, till the present day where 'organised crime' has moved into higher circles. It could be considered the underlining of the statement that 'organised crime always adapts' itself to new circumstances and opportunities. Is that correct? If it is the same criminals who change their criminal enterprises and adopt new skills, the statement is correct. However, when changes bring other perpetrators to the criminal playground, 'organised crime adapts' is no valid proposition. One can only say that new opportunities requiring new skills also attract another population of criminal entrepreneurs which subsequently changes the OC construction. Following the author's account of the variable Czech OC scene closely, we notice indeed that he presents a different population than the 'usual' one: a sophisticated and institutionalised class of entrepreneurs having found a comfortable place in the warm chambers of the better circles (Scheinost, 2013).

We find a very usual organised crime population, described by Toine Spapens in his chapter on Italian criminals in the Netherlands. Why this interest? This has long roots, going back to the late 1980s and 1990s when with the rising fear of organised crime, alarms were also raised about the mafia 'crossing the Alps' northward to the Netherlands. More than at present the official organised crime constructions were to a high degree fed by fear mongering, evoking emotions and threat images (Van Duyne, 
2004). Nevertheless, it was not all fantasy: occasionally there were indications that members of the four Italian organised crime groups were in the country for other reasons than the Van Goch Museum: hiding for the Italian prosecution or planning new cocaine smuggling operations to Italy. To assess whether the Italian criminal presence should be considered a threat, particularly subverting the democratic rule of law in the Netherlands, the Cerca Trova team ("search and thou shall find") made an elaborate stock taking. And indeed, the team found indications of an Italian organised crime presence in the Netherlands: stretched over a time span of 25 years (1989-2014) there were 461 relevant observations mainly related to drugs trade (cocaine), and only 9 concerning extortion, in Italy the core business of OC groups. While some of the team jumped to an Italian OC presence with all the connected constructions, the author weighed the plausibility of long-term integrated Italian legal presence against the scarcity of typical OC (Camorra, 'Ndrangheta, etc.) information. He thought that finding odd: mafia presence needs to be recognised and 'respected' in order to have power. But to become respected implies to be seen, which is bound to come to the notice of the police. This did not happen. So yes, there are OC related Italians in the Netherlands, but this does not support the proposition of a subversive 'mafia threat'.

In the literature on organised crime and terrorism one can find many worrying constructions on the interconnectedness or 'nexus' of these two phenomena. This is assumed for terrorist financing, particularly regarding the acquisition of weapons. While sensational and speculative publications abound, empirical evidence is again scarce; at best anecdotal, such as in the Western Balkan during the 1990s (Prezelj, 2010). In a refreshing way, without allowing themselves to be burdened by speculative constructions Niels van Wanrooij and Saraï Sapulete undertook an inductive bottom-up investigation of the interconnectedness of organised crime and jihadi terrorist networks in the Netherlands. To that end they used the Social Network Analysis, and applied this to the 'raw' police data which had been filtered for 'firearm possession', 'firearm dealing' and (suspected) terrorism. From the resulting database of 40 persons relationships were mapped: five arm dealers, 15 suspected terrorists and 20 persons with a conviction related to fire arms. It was found that suspected terrorists had a one or twostep connection to the firearms dealers, confirming the link between criminal offenders and terrorism. But otherwise the findings did not reveal a 
coherent terrorist network in the Netherlands. There were interactions between criminals and terrorist suspects, some of whom also had a criminal record before their conversion to jihadism, but the authors could not qualify this finding as interconnectedness at a structural level. Though recent terrorist arrests demonstrate there are 'terrorist cells' in the country, the evidence is insufficient to justify an organised crime and terrorist nexus. Scientifically the chapter follows the rule of parsimony in deleting another speculative construction.

\section{Corruption and integrity}

Many criminal events occur as a fate, something sudden, not as a daily experience: the 'daily fate' is grammatically not wrong, but still sounds odd. But how should you construct a fateful reality which implies a daily criminal burden, mostly of a moderate nature but influencing your life nevertheless? That is the case when corruption has grown into a way of daily life, whether you like it or not: it has become a daily cost of getting various things done, from waving a parking ticket to getting your doctor degree. Of course, if you can compensate these corruption expenses by levying corruption fees yourself, you can in the end of the month or year determine whether you have succeeded to remain at the 'sunny' side of the corruption break-even point. So you can be a corrupt winner or a loser. As is the case with the legal economy, also at the social-economic bottom the corruption balance is negative: corruption rarely favours the underprivileged. No surprise that many people demonstrate an ambiguous attitude to corruption, as investigated by Anna Markovska, Alexey Serdyuk, Petrus C. van Duyne and Konstantin Bugaychuk. In their 2017 survey of citizens in Kharkiv, the second town of Ukraine, they found views, reflecting a similar ambiguity or even duplicity: condemning corruption goes side by side with condoning or even positive statements and confession of a willingness to offer bribes voluntary, without being solicited or extorted. (See for Bosnia, Datzer et al., 2008). Small wonder that at higher political level there is not much political will to fight corruption. In fact, the institutional progress that has been made after 2014, was achieved under tough pressure of the international donors, threatening to withdraw funds if legislative and institutional reforms would not be implemented. It was a process of a drawn out foot- 
dragging as was the case with the new Anti-corruption Court, from the President downwards, obstructing and slowing down by every step. ${ }^{5}$

A large part of the public displays a clear resignation to the present corrupt landscape furthered by the opaque public administration with its closed windows and doors. This was also a characteristic of the police forces: an opaque and inward directed military organisation (militsiya), also considered highly corrupt. But after the Maidan Revolution (in which the police role was seriously criticised), a new police reform was carried out. Its most visual element was the introduction of a separate branch, the Patrol Police. Socio-psychologically, the most important element was citizen's confidence: police performance is supposed to be reflected in and measured by the confidence the public has in its police force. Naturally it is important to learn how the police reflect on their own role in this reform: what do they experience of this public trust? This part has been investigated by Igor Sviatokum, Alexey Serdyuk and Petrus C. van Duyne as presented in their chapter on police reform. Based on the responses of 479 officers the authors observe that the results are modest: between 40 and $50 \%$ of the respondents saw little change, with the exception of the Patrol Officers who thought the reform went into the right direction. In addition to the public trust perception, the research also asked the officers to assess the police organisation as a "fair employer". It appeared that the fairness scores for the employer were generally low, whether related to protection of officers in court, fair pay, care and support in sickness or otherwise officers in need of support. This is important for maintaining confidence and integrity in a law enforcement agency: this is no construction but a real-life basic condition.

How important such a trust is or the lack thereof, is not only apparent by the recent history of Ukraine, but is also borne out by a study in neighbouring country Moldova as described by Petrus C. van Duyne and Brendan Quirke in their chapter.

There are many reasons to compare the two countries for similarities and differences. The most important is their Corruption Perception Index:

\footnotetext{
5 Anastasia Krasnosilska: http://khpg.org/en/index.php?id=1529358373. This is not unique to Ukraine: Van Duyne and Stocco (2012) observed a similar lack of 'political will', rather personal attitude of a corrupt elite in Serbia.
} 
30 for Ukraine and 31 for Moldova: the absolute bottom for Europe. Another similarity is that also in this country virtually no anti-corruption law would have been enacted or measure implemented if not accompanied by international (financial) 'arm twisting'. There is one interesting difference: in Ukraine there is still a plurality of oligarchs who more or less can balance each other (if they do not conspire) (Konończuk et al., 2017). Such a 'democracy of oligarchs' is absent in Moldova: after a protracted political struggle the oligarch with the largest political and law enforcement clout, Plahotniuc, succeeded in getting his rival, Filat, indicted and convicted in 2016 to nine years imprisonment for the ill-famous one billion dollar fraud and laundering. ${ }^{6}$ The principle accomplice in this scheme, Mr. Shor, was convicted to 7,5 years. Notwithstanding this conviction, Mr. Shor's sentence has thus far not been executed. He was allowed to remain at large, establish his own political party and succeeded in the February 2019 election to get a seat in Parliament. It is one of the most recent examples of 'capturing the state' by criminal oligarchs, in this case the only one left. By massive funding he 'owns' the Democratic Party, controls the majority of media outlets and influences legislation and judiciary nominations. Altogether Moldova represents an almost classical example of a 'captured state'. Are there no institutional guardians against corruption? Yes there are, such as the Anti-Corruption Prosecution Office, led by persons of questionable expertise, underfunded and burdened with small corruption cases that could also be delegated to a local prosecutor. These sub-modest efforts allow the government to state "We are on the right track", without moving much forward.

\section{Policy and businesses in foggy constructions}

Money laundering is one of the criminal law constructions that has become perceived as an entity in its own right. It shares this status with the adjacent concept of 'organised crime' with which it also shares a high degree of lack

6 Though Filat denied any guilt, summer 2016, his son (22) arrived in the UK, and in a not too sophisticated laundering action paid $£ 400.000$ in rent upfront for a penthouse in Knightsbridge, spent $£ 200.000$ on a Bentley and received a recovery order of over nearly $£ 500.000$.

https://www.theguardian.com/world/2019/feb/07/court-orders-son-moldovaformer-pm-pay-466000 
of clarity. Both also haunt us since the late 1980s (Van Duyne et al., 2018). They are also classic examples of what impact a foggy concept can have on the apparatus of law enforcement. But money laundering encompasses an extra action circle: the whole financial industry and related non-financial sectors. This would not be so bad if clarity would have been served, which is not the case. This is one of the lessons the reader can learn from the chapter by Brigitte Slot and Linette de Swart about the attempt of the Financial Action Task Force (FATF) to evaluate the outcome of its policies, per country. Methodologically this is as ambitious as doing the Dakar Rally with an old 2-CV without mileometre and compass. Indeed, as the authors make it clear: the car is bound to run into the sand, if it can start at all. Basic methodological principles are violated: no concept clarity or proper operationalisation, no problem delineation and no zero measurement, to mention just four mortal methodological sins. This is not the whole story: we can observe a kind of real-life sociological experiment of collective make-belief: while before the start at Dakar the 2-CV stands already with its four wheels until its axes in the sand, all stakeholders around shout for joy that it is moving fantastically. A whole evaluation story is constructed: one after the other mutual evaluation report is stacked together with countries' national risk assessment, but we still cannot determine any outcome regarding the effectiveness of all these exploits, as also observed by Ferwerda (2018). The authors observe that the FATF outcomes are "predominantly the result of international negotiations, rather than strict analytical thinking", which is hidden behind the aplomb with which these are presented.

Another construction with undeniably clouding effects is elaborated in the final chapter of Matjaž Jager, Ciril Keršmanc and Katja Šugman Stubbs. It concerns 'corporate social responsibility', a construction of moral rules for the conduct of multi-national corporations. As such it has an inherent social acceptability, but, as the authors indicate in the title, it is rather used as a mask for various forms of corporal misconduct. Naturally there is a tension between the basic aims of the multinational: earning money and satisfying the shareholders on the one hand, and being morally accountable to the society on the other hand, if only by lip service to avoid criticism. But to what society? And where and who is the responsible legal person, when there is a mother company with daughters spread over multiple countries? All connected branches will have ethical codes of conduct 
which will be presented as tokens of corporate social responsibility. However, what happens behind this slick PR behaviour? The authors provide examples from the oil industry that clearly contradicts the tenets of its own social responsibility, particularly when they operate in countries with a flawed, corrupt governance. The authors even apply the analogy of the human psychopathy to the attitude and conduct of the corporate persons: deceptive, charming, rationally scouting for weaknesses, lack of sympathy for the victims, no remorse and, with an inflated ego, persistent in their claims of having done the best, pointing at philanthropic or ecological projects to 'greenwash' their corporate misbehaviour. Nevertheless, there is a silver lining. Like most constructions, once corporate social responsibility is consistently upheld by a large enough part of civil society, it will get a life of its own. That is good as it can be invoked to hold wrong-doers responsible, whether in court or in public.

So, although the world is shaped by constructions, some of them foggy mind projections, is does not mean that they cannot have a beneficial effect if actively invoked.

\section{References}

Datzer, D., A. Maljević, M. Budimlić and E. Muratbegović, Police corruption through eyes of bribers: The ambivalence of sinners. In: P.C. van Duyne et al., European crime-markets at cross-roads. Extended and extending criminal Europe. Nijmegen, Wolf Legal Publishers, 2008.

Duyne, P.C. van, The creation of a threat image: Media, policy making and organised crime. In: P.C. van Duyne, M. Jager, K. von Lampe and J.L. Newell (eds.), Threats and phantoms of organised crime, corruption and terrorism. Nijmegen, Wolf Legal Publishers, 2004.

Duyne, P.C. van, J.H. Harvey and L.Y. Gelemerova, The critical handbook of money laundering. Policy, analysis and myths. London, Palgrave Macmillan, 2018.

Duyne, P.C. and E. Stocco, Corruption in Serbia. From black box to transparent policy making. Nijmegen, Wolf Legal Publishers, 2012. 
Ferwerda, J., The effectiveness of anti-money laundering policy: a costbenefit perspective. In: C. King, J. Gurulé and C. Walker (eds.), The Palgrave handbook of criminal and terrorism financing law. Cham Switzerland, Palgrave Macmillan, 2018.

Galeotti, M., The vory. New Haven, CT., Yale University Press, 2018.

Heather, P., Empires and barbarians. Migration, development and the birth of Europe. London, Macmillan, 2009.

Herkes, G., The Janus-faced victimisation in human smuggling and human trafficking. In P.C. van Duyne et.al., The Janus faces of cross-border crime in Europe. Den Haag, Boom Uitgevers, 2018.

Kernteam Noord en Oost Nederland. Algemene Criminaliteitsbeeldanalyse Oost-Europa, 2000-2001, Zwolle, 2001.

Konończuk, W., D. Cenușa and K. Kakachia, Oligarchs in Ukraine, Moldova and Georgia as key obstacles to reforms. 2017 www.3dcftas.eu/. von Lampe, K., Organised crime. Analysing illegal activities, criminal structures and extra-legal governance. London, Sage Publications, 2016.

Norwich, J.J., The popes. A history. Amsterdam, Uitgeverij Bert Bakker, 2013.

Nguyen, T. and K. von Lampe, On the persistence of an open illegal market: Explaining the continued existence of street-vending of contraband cigarettes in Berlin since 1990. In P.C. van Duyne et.al., The Janus faces of cross-border crime in Europe. Den Haag, Boom Uitgevers, 2018

Prezelj. I., (2010). The small arms and light weapons problem. In W. Benedek et al., Transnational terrorism, organised crime and peace building. Human security in the Western Balkans. Houndmills, UK, Palgrave Macmillan, 2010.

Rawlinson, P., Mafia, media and myth. Representations of Russian organised crime. The Howard Journal of Criminal Justice, 1998, 4, 346-358.

Scheinost, M., Organised crime in the country of transition after twenty years. In P.C. van Duyne et al., Human dimensions in organised crime, money laundering and corruption. Nijmegen, Wolf Legal Publishers, 2013.

Siegel, D., Maffia, diamanten en Mozart. Den Haag, Boom Juridische Uitgevers, 2010. 